有機絶縁物のトラッキング現象と火災

\author{
木下勝博 \\ 科学警察研究所 \\ 干277-0882 千葉県柏市柏の葉 6-3-1
}

\title{
Tracking Phenomenon and Fire of Organic Insulating Materials
}

\author{
Katsuhiro Kinoshita \\ National Research Institute of Police Science \\ 6-3-1 Kashiwanoha, Kashiwa, Chiba 277-0882, JAPAN
}

(Received 8 March 2001; accepted 21 December 2001)

Tracking phenomenon, to put it plainly, is the phenomenon to form the carbonized electrical track and lose insulation in the part with potential difference on the surface of insulating materials. Tracking resistance means the difficulty occuring the tracking phenomenon of the organic insulation materials. Studies on the tracking phenomenon and the method of evaluating tracking resistance has been often reported on so far. But, there are only a few comprehensive researches and commentaries which include tracking phenomenon and the fire which occurs by the tracking phenomenon. Hence, I decided to explain tracking phenomenon of the organic insulating materials and the phenomenon that developed concerning the fire which develops and is called, tracking fire. Tracking phenomenon is discussed first. Next, cases of tracking fire in electric wiring and the wiring utensil and the studies on the cause of tracking fire are explained. Furthermore, prevention of tracking fire and future problems are also discussed.

Key words: Tracking phenomenon, Tracking fire, Carbonized electrical track, Tracking resistance

\section{1. はじめに}

ポリ塩化ビニルや合成ゴムのような有機絶縁材料 には，軽くて弾性があり，しかも絶縁性が高いとい ったような沢山の長所があり, 電気絶縁材料とし て，なくてはならない存在となっている，一方，有 機絶縁材料には，他の材料に比べて耐熱性が劣り， 熱分解し易く，使用を誤ればトラッキング現象を起
こして火災の危険性を生じるという短所も併せ持っ ている.

このトラッキング現象というのは, 有機絶縁材料 の劣化要因である熱劣化, 電気的劣化および放射線 劣化のうちの電気的劣化に該当する現象である．卜 ラッキング現象とは, 簡単に言うと絶縁物表面上の 電位差のある部分に炭化導電路を形成し, 絶縁性を 失うことである。トラッキング現象は, 第一次世界 
大戦後のイギリス海軍の艦船の電気設備に使用され たベークライトに焼損痕跡が形成されたことから発 見されたと言われている11. また，当時の艦船内の 電気器具類の設置状況を想像すると, 炭塵, 油煙, 媒煙，塩分などのほか湿気や水分などの影響を最も 受け易い場所であったと考えられることから，この 間題が注目されたのは無理のないことと言われてい $る^{22}$. その後，有機絶縁材料の長所を生かし短所を 抑えた，新しい材料の開発や様々な改良が行われて きている．また，それを評価するための様々な試験 法も開発されてきている.しかし，トラッキング現 象は依然として発生している。 また，これによる火 災，すなわちトラッキング火㷋も後を絶たないのが 現状である3,4).

有機絶縁材料のトラッキング現象の起こりにくさ は耐トラッキング性と呼ばれており，トラッキング 現象および而トラッキング性の評価法などについて の研究や解説はこれまでに数多く報告されてい $3^{1,5-18)}$. しかし，トラッキング現象が更に進展し て生じる発火現象も含めた総合的な研究や解説は比 較的少ない2,19-24)。そこで，有機絶縁材料のトラッ キング現象抢よび，この現象が更に進展して発生す るトラッキング火災についての解説を試みることに した.

本稿では，先ずトラッキング現象について述べ る. 次に電気配線や配線器具類におけるトラッキン グ火災の事例抒よび原因究明について述べる。ささら に，トラッキング火災の事故防止抢よび将来の課題 について述べる.

\section{2. トラッキング現象}

\section{1 メカニズム}

有機絶縁物の表面が湿気などで污損された状態で 電圧が印加されてその表面に電位差が生じると, 電 位差のある部分で電流が流れてジュール熱が発生す る。そしてその熱のため，絶縁物表面が部分的に乾 燥し, 液脈の導電路が分断されて表面絶縁抵抗が高 くなる。その結果，電界が不整となり，シンチレー ション（局部的な微小発光放電）を生じ，その熱に よって, 絶縁物の一部が分解され, 炭化物が生成す る.この炭化生成物の導電率が大きいため，その先
端に電界が集中し，更にその周辺に炭化物を生じて これが電極間に伸び，最後に全路破壊に至るという のが一般的な絶縁破壊の進行形態である1,2,6). した がって，トラッキング現象を引き起こす直接的原因 となるのは放電熱であり，それをもたらす絶縁物表 面の湿気や污染は間接的原因となっている.

このようにシンチレーションによって有機絶縁材 料表面に炭化導電路が形成されるような現象をトラ ッキング現象と呼んでいる。 また，この場合に形成 された炭化導電路をトラックと呼んでいる。トラッ ク（track）というのは電気の通った跡というよう な意味である，すなわち絶縁材料の表面には電流の 通った跡が観察されることからトラッキング （tracking）という用語が生まれたのである。炭化 導電路（トラツク）の様相は，直線状あるいは樹枝 状などいろいろあるが，それらは材料の種類，トラ ックの形成過程に抢ける多くの因子の影響を受けて 異なる1,2,6,9,17).

一般にトラッキング現象は，これまでに述べたよ うに電気工学的観点から絶縁破壊までの現象に視点 を置いた用語として使われている。一方，火災科学 的観点から燃焼までも含めた現象に視点を置き，卜 ラッキング現象によって生じた炭化導電路に短絡電 流が流れるなどして絶縁物が着火する現象を，グラ ファイト化現象または金原現象と呼ぶ場合があ る19,22-26). また，木材に抢いてもトラッキング現象 が起こる可能性があり，これによって木材が燃焼す る現象をグラファイト化現象または金原現象と呼ぶ 場合もある $22,23,26-31)$ 。さらに，電圧が印加された有 機絶縁材料の表面に何らかの原因で発生するシンチ レーションによって炭化導電路が生成すればトラッ キング現象，有機絶縁材料が電気火花に曝されてそ の表面に微少な炭化導電路が生成すればグラファイ 卜化現象と呼ぶこともある19,22-23). しかし，いずれ の場合も発生の過程が異なってはいるものの, 絶縁 材料表面での放電によりその材料中の炭素がグラフ アイト化して炭化導電路を形成する点では共通して おり，トラッキング現象に含まれる.

\section{2 各種要因}

トラッキング現象を起こす要因としては種々のも のが考えられるが，一般には湿気や污染物（塩分， 
無機質および繊維質のちり, 化学薬品類) が挙げら れる，そして，これらが絶縁物表面に付着すること により，シンチレーションが生じて絶縁破壊に至る ことが多い。トラッキング現象の起こし易さは，基 本的には材料自身の特性により決まるものである. しかし, 絶縁破壞に至る過程は, 各種の要因, たと えば材料表面の湿潤条件, 污染物の種類, 材料と接 する金属の種類，この金属に加わる電圧，放電発生 時の放電の形態とそのエネルギー，炭化生成物など が相互に関連し合っており，極めて複雑な様相を示 す $1,2,6,9)$.

我国のように高温・多湿となり易い環境条件にお いては, 有機絶縁材料表面の湿気の影響は特に重要 である，そこで，霧による有機絶縁材料表面の濡れ とそれが放電開始に及ぼす影響についての検討が行 われた。 そして，接触角の大きな試料ほど濡れにく く放電開始時間が長くなることが明らかにされ た ${ }^{32)}$ 。 また，絶縁材料の湿潤については，材料固有 の濡れ易さと電極間での污損液の挙動が問題とな る。そこで，材料表面で放電が発生するまでの時間 の測定や各種材料の接触角の測定が行われた。 その 結果，材料により放電の発生時間は異なり，濡れ易 い材料ほど放電が発生し易いことが明らかにされ た ${ }^{33)}$.さらに，污損液の種類も同様にトラッキング 破壊の生じ易さを変化させる，界面活性剂を含む污 損液を用いると材料表面は濡れ易くなり，このため 放電が生じ易く，トラッキング破壊に至り易くな る.このように材料の耐トラッキング性を検討する 場合，材料の濡れ易さ抢よび污損液の種類を十分考 慮する必要のあることが指摘されている9 .

絶縁材料表面の污損液中を電流が流れるとジュー 儿熱が発生して水分が蒸発する. 蒸発が進むと水の 膜に切れ目が生じるが，これを乾燥帯と呼んでい る.この乾燥帯が生じて電流が遮断される瞬間に, その箇所にシンチレーションが発生する. 一方, 有 機絶縁材料は銅や黄銅などの金属導体を電気的に絶 縁するために用いられるものであり, 電圧印加時に おいて絶縁材料が湿潤あるいは污損されると, 污損 液と金属間で電気化学反応により金属が溶出され る。一般に導体として使用される金属は銅または黄 銅であり,これらの金属は污損液との電気化学反応
を生じ易い，溶出金属としては，電極の成分に関係 しその塩化物, 水酸化物の形で析出する. 溶出金属 は，乾燥帯の幅を狭くするために，放電が生じ易く なるものと考えられている14,34-37).

一般家屋に電力会社から供給される電気は, 50 $\mathrm{Hz}$ または $60 \mathrm{~Hz}$ の低圧交流である。一方, 自動車 ではバッテリーが電源として用いられており，これ は低圧直流である。そこで，直流と交流による耐卜 ラッキング性の比較検討が行われた. その結果, 電 極材質による耐トラッキング性の評価の序列は, 直 流と交流とで逆転すること, 直流の場合のトラック は面状に形成されるのに対して，交流の場合のトラ ックは線状に形成されることが明らかにされ た7,36,38).

以上, トラッキング現象を起こす要因の幾つかに ついて述べたが，これらは相互に絡み合って作用し ており，極めて複雑である.

\section{3 試験方法}

耐トラッキング性の優れた絶縁材料の必要条件と しては, (1)撥水性に優れ, 濡れにくいこと, (2)熱分 解しにくいこと, (3)熱分解してもガス化し易く残留 物を残しにくいこと，(4)主鎖にベンゼン核を有しな いこと,などが挙げられる8,12,17,18)。これらの条件 を備えるために，材料自体，充填剂抢よび硬化剂な どの研究が行われている13,14,39). 特に, エポキシ樹 脂は他の有機絶縁材料に比べて, 充填剤, 硬化剂な どの添加，その方法および，硬化温度などの製造条 件の違いにより特性の異なるものが得られるという 独特な性質を持っており, 耐トラッキング性向上の ための活発な研究が行われてきた ${ }^{40-43)}$ 。また，これ と並行して，耐トラッキング性を客観的に評価する ための耐トラッキング性試験が行われてきた6).

一般にある使用目的のために様々な種類の有機絶 縁材料の中からある特定の材料を選択する場合, 具 体的なデータに基づいて合理的に選択する必要があ る. そこで, 各種有機絶縁材料の耐トラッキング性 試験が行われるようになった。しかし, 実際に起こ るトラッキング現象は, 様々な要因が複雑に絡み合 っているため, 耐トラッキング性試験による評価 を，それぞれの有機絶縁材料の特性だけに基づいて 行うことができないという問題が生じた。このよう 
なことから，実際の現象を考慮した，DIN法，BS 法, ダストフォッグ試験などといった特徴のある数 多くの耐トラッキング性試験法が提案されてきた. そして，それぞれの試験法について1952年から IECにおいて国際的に検討を重ねた結果, IEC Publication 112 として, 推奨試験法の形で発表され た6). その後，わが国でも電気学会が中心となって トラッキング現象に関する様々な問題についての共 同的検討が始まった. 以後, 関連する専門分野の技 術者などの関心を集めながら現在に及んでいる。ま た, IEC Publication 112は, その後数回の改訂を経 て1979年に Publication 112 (第 3 版）となり9,10), この第 3 版が，1997年から IEC 60112 (1979-01) と呼称を变更されて現在に至っている.

以下，代表的な耐トラッキング性試験である， IEC 60112 （1979-01）の試験方法について紹介す る.

Fig. 1 に電極形状とその配置を示す。同図におい て, 試料面上に幅 $5 \mathrm{~mm}$, 厚さ $2 \mathrm{~mm}$, 試料面と接 する部分が直線状となるように先端角度を $30^{\circ}$ とし た白金電極を試料面と $60^{\circ}$ の傾斜をなすようにし， 4 $\mathrm{mm}$ 間隔で相対向するように配置する．試験溶液に は，溶液 $\mathrm{A}, \mathrm{B}$ の 2 種類がある。溶液 $\mathrm{A}$ は, 塩化ア ンモニウ $0.1 \pm 0.002 \%$ 水溶液（抵抗率： $23^{\circ} \mathrm{C}$ で $395 \pm 5 \Omega \cdot \mathrm{cm})$ である. 溶液 $\mathrm{B}$ は，塩化アンモニ ウム $0.1 \pm 0.002 \%$ ，アルキルナフタレンスルホン酸 ナトリウム $0.5 \pm 0.002 \%$ の混合水溶液（抵抗率 : 23 ${ }^{\circ} \mathrm{C}$ で $\left.170 \pm 5 \Omega \cdot \mathrm{cm}\right)$ である。溶液 $\mathrm{A}$ または $\mathrm{B}$ のい ずれかの電解液を 30 秒に 1 滴 $20 \mathrm{~mm}^{3}$ ずつ電極間の 試料面上に滴下させ，試験電圧は連続印加しながら 試験を行う．Fig. 2 に耐トラッキング性試験回路を 示す．試験回路条件としては，電極 7 を短絡したと き各試験電圧において短絡電流が $1 \mathrm{~A}$ となるよう に可变抵抗器 4 によって調整する。電源には商用周 波数の単相交流を用い，変圧器 2,3 により $600 \mathrm{~V}$ ま で任意に調整できるようになっている，この試験に おいて， $0.5 \mathrm{~A}$ 以上の電流が 2 秒以上流れた場合を トラッキング破壊と判定し，電源が遮断されるよう に過電流継電器 1 を設定する. 試験は電解液滴下数 101摘まで継続して行い, それまでにトラッキング 破壊が起こらない場合は侵食として取り扱う。

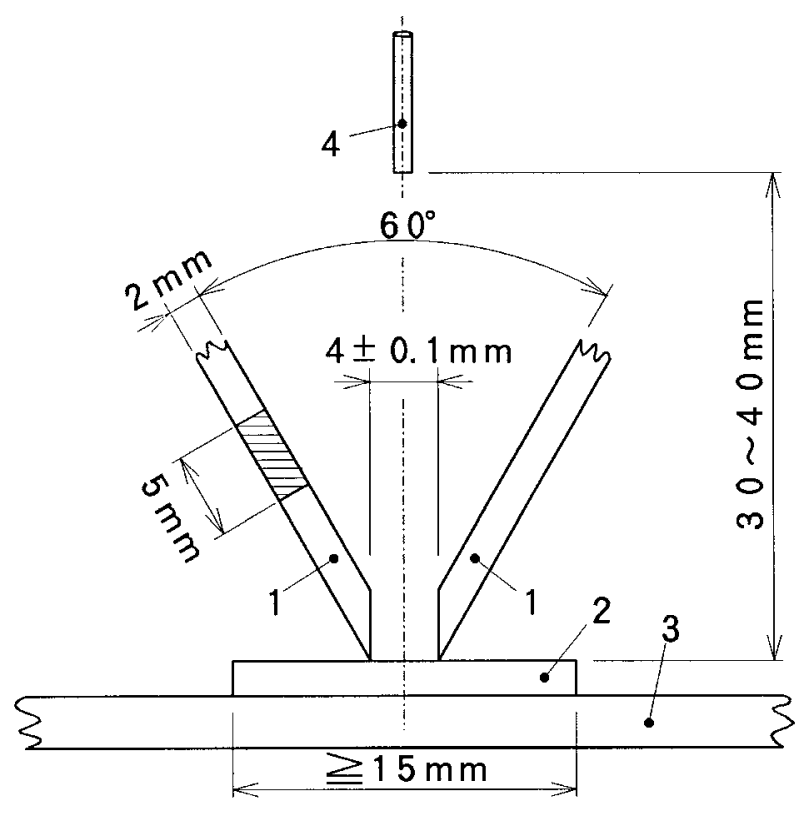

Fig. 1 Dimensions and relative arrangement of electrodes and specimen.

1: Electrode, 2: specimen, 3: support, 4: tip of dropping device.

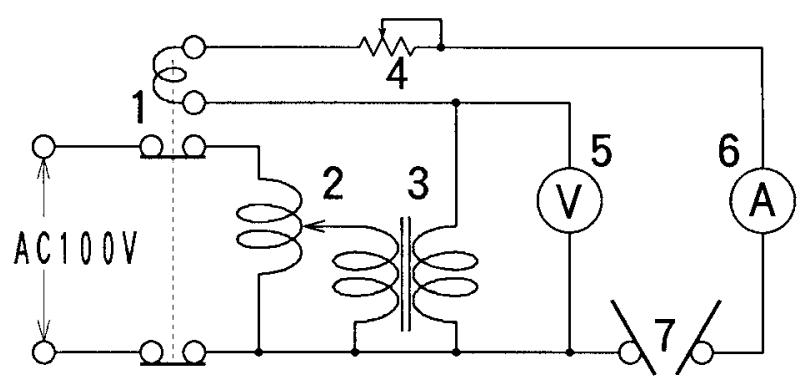

Fig. 2 Testing circuit for tracking resistance.

1: Delay overcurrent relay, 2: variable voltage transformer, 3: transformer, 4: variable resistor, 5: voltmeter, 6: ammeter, 7: electrodes.

耐トラッキング性の評価法として， IEC 60112 (1979-01）では次のように，CTI（comparative tracking index ; 比較トラッキング指数）と PTI (proof tracking index; 保証トラッキング指数) の 2 種類を提案している.

(1) CTI：100〜 600 V の範囲内で， $25 \mathrm{~V}$ 間隔で 電圧を印加し，電解液の滴下数が 50 滴で， 5 個の試 験点すべてがトラッキング破壊に至らない最大の電 圧を意味する．たとえばこの電圧が $400 \mathrm{~V}$ の場合に 
は“CTI 400”（A 液の場合），“CTI 400M”（B 液 の場合）のように表示する.

(2) PTI：175 V，250 V，300 V，375 V あるいは $500 \mathrm{~V}$ の試験電圧を推奨している. 上記 5 種類の試 験電圧のうちの一つに定めてトラッキング試験を行 い，その結果を“PTI 175で合格”あるいは“PTI $175 \mathrm{M}$ で不合格”のように表示する.

なお，実際に用いる導体のほとんどすべてが銅や 黄銅であるにもかかわわらず，電極材質に白金を用 いるのは，銅や黄銅の電極の場合に比べて試験時に おける電極の溶出による影響および測定值のばらつ きを少なくするためである象． また，この場合の 試験結果がトラッキングに至らず侵食になる材料は 耐トラッキング性が高いと評価することになるが， 実際の使用状態ではトラッキング破壊を起こすもの があり, 注意を要することが指摘されている6,9).

\section{3. トラッキング火災}

一般の低圧電気器具にはネジ止めなどの接続部が あるのが普通である。これらの接続部は, 使ってい るうちに緩みを生じることがある。この原因として は, 機械的な振動の他に通電電流の断続によるネジ 部の膨張収縮が挙げられる。もし接続部が緩むと， その部分の電気抵抗の増加による発熱量の増加とな り，温度上昇をまねくことになる。また，コードの 付け根などでは, 屈曲の繰り返しによって絶縁被覆 内の心線の一部が断線することがあり，このような 状態を半断線と呼んでいるが，この場合も，半断線 の部分での電気抵抗の増加による発熱あるいは電気 火花の発生をまねくことになる場合がある。さら に，心線に損傷を与えた場合なども類似の現象が生 ずる恐れがある．これらはいずれも絶縁被覆の熱劣 化をまねくことになる，一方，近頃の機密性の高い 住宅では, 室内の空気中の水蒸気が冷たい壁に触れ て水滴となる現象, すなわち結露が起こり易くなっ ている，そのため，このような条件が絶縁被覆の熱 劣化に重畳してトラッキング現象, さらにはトラッ キング火災へと進展し易くなっている.

\section{1 事例研究}

火災が発生すると, 直ちに原因究明の調查活動が 開始される。しかし，火災現場における火災鎮火後
の原因調査の時点においては, ほとんどの場合, 電 気製品や電気配線類などの物的証拠資料の一部なた は全部が焼失している，その上，焼け残った証拠資 料も, 避難, 消火, 人命救助などの様々な活動の段 階に掞いて，移動したり破壊していることが多い。 そして，火災現場におけるこのような困難な条件の 基で, 残焼物などの物的証拠資料の採取, 位置関係 の測定および写真撮影などが行われる。 また，火災 進行状況の目撃証言などの人的証拠の収集が行われ る ${ }^{44)}$.このようにして, ある程度証拠資料が揃った 時点で，これらの資料を基に総合的に判断して出火 原因の仮説が立てられる.この時, 仮説を 1 本に絞 り込めれば能率のよい火災鑑定ができることにな る.しかし, もし收集した資料の検査・分析結果な どから仮説が否定された場合，新たな仮説を立てて これに必要な証拠資料を得ようとしても, 既に火災 現場が破壊されて必要とするものの形や寸法などが 分からなくなっているといったような取り返しのつ かないことが起こる恐机ある，そこで，このよう なことを防ぐため, 幾つかの仮説を立て, これらの 仮説の検証に必要な証拠資料の収集を行うことが必 要とされる，ところが，火災鑑定においては，証拠 となるものが，変性したり焼失したりするため，仮 説の検証に必要な物的証拠資料の収集には限界があ る. しかも炎苂の現象は, 着火源, 可燃物, 両者の 位置関係, 周囲条件などの僅かな違いが燃焼状況に 大きく影響する極めて複雑な挙動を示す．そのた め, 幾つも挙げたそれぞれの仮説を積極的に立証す ることが困難であり, 可能性の低い仮説を除いて行 く消去法が火災鑑定に打ける一般的な手法となって いる.このようにして, 火災鑑定において出火原因 が特定され，貴重な事例として警察や消防に数多く 保存されている。 そこで, 火災の発生原因や再発防 止を考える際，一般の火災の場合は勿論のこと，卜 ラッキング火災の場合においても, 過去に起こった 類似の事例が公表されておれば，これらを参考資料 として活用することにより, 効率的な火災鑑定を行 うことが出来るものと考えられる。また，そのため には，貴重な事例を活用し易いように分類整理して おく必要があると考えられる. 以下, 火災事例の概 要について述べる. 


\subsection{1 配線類からのトラッキング火災事例}

$600 \mathrm{~V}$ ビニル絶縁平形ビニル外装ケーブル, 略称 F ケーブルは，これを用いた配線の施工が比較的簡 単で作業能率がよく, 経済的である等の理由から屋 内用配線ケーブルとして多用されている. そのた め, 他の屋内用電線に比べて Fケーブルの出火も 比較的多く, これの出火事例が報告された ${ }^{45-48)}$.こ のうちの和服問屋の倉庫火災の報告45)では，火災現 場の調査結果を基に F ケーブルの絶縁被覆の損傷 程度, 漏電電流の大きさおよび漏電したトタン板の 種類を変えて再現実験を行い，F ケーブル絶縁被覆 の損傷による出火のメカニズムが調べられた。ま

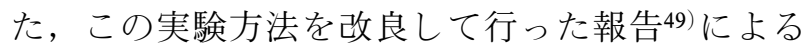
と, 2 心の $\mathrm{F}$ ケーブルの絶縁被覆に特定の損傷を与 え, その損傷部に波形のトタン板が断続的に接触 し， $\mathrm{AC} 100 \mathrm{~V}$ を課電してその接触部に地絡電流が 流れる場合に限定して, その発火の形態と発火に至 る過程などが実験により検討された。さらに，ある 木造モルタル 2 階建店舗において, 三相 $200 \mathrm{~V}$ を印 加されたルームクーラー用の三相 $\mathrm{F}$ ケーブルのト ラッキング破壞が火災の発生原因と判定された事例 が報告された ${ }^{2)}$ 。この場合の発火部は, F ケーブル が建物外壁を構成する波形トタン板の合わせ目から 建物内に入った部分であり, F ケーブルの心線に電 気火花による溶融痕跡が認められた。 また, この溶 融痕跡と全く同じ位置で波形トタン板にも電気火花 による溶融穴が認められた. さらに, 当日の気象状 況から波形トタン板の合わせ目, およびトタン板に 人為的にあけた穴などから，Fケーブルや IV 線を 伝わるなどして, 雨水が屋内に侵入したと考えられ ることから, これらの条件を設定し, ケーブルの心 線とトタン板が，污損液を介して不完全接触を繰り 返す場合についての再現実験が試みられた。その結 果, トラッキング現象が起こって絶縁被覆が着火然 焼することが確認された。なお，以前から一般に雨 水は蒸溜水であるため電気の不導体, すなわち絶緑 物として取扱われていた。 しかしながら, 雨滴は上 空に抢いてイオンを有する場合のあること, 大気中 の污染の影響を受けることなどが知られており, 特 に建造物や電線などを伝わってきた雨水は, 種々な 污染物質を含んでいると考えられるから, 常に電気
的な絶縁性を有するとは限らないことが指摘され た。 また，体積抵抗率の実測により，雨水が常に不 導体であるとする考え方や取扱いは不十分なことが 指摘された2).

一方，木造モルタル 2 階建ての住宅の玄関上部の 内壁から出火した事例が報告された46)。この住宅は 比較的新しく, 出火当日, 玄関のシャンデリアを点 灯したが，暫くしてシャンデリアの電球が点滅し始 めたのでスイッチを切った。 その約10分後に，家人 が「パチパチ」という物音を聞きつけ，玄関上部の 内壁が燃えているのに気付いたものである。焼損し た単相三線式配線の F ケーブルはステップルで柱 に固定されており，ケーブルの心線の状況について は，赤相と中性線が $2 \mathrm{~mm}$ に亘って荒れた凹部分が 生じ，その部分が細くなっていた。被災ケーブルと 同じ仕様のケーブルを用い，100 W の電球負荷を接 続して AC100 V を印加した状態で再現実験が行わ れた。人為的に損傷させた絶縁被覆の部分に $0.5 \%$ 食塩水を滴下して実験を行った後に，損傷部分の絶 縁被覆を取り除いて心線の状況を顕微鏡により観察 したところ，被災した心線と同様に凹部分に荒れた 面が見られた。このことから，絶縁被覆の損傷によ り露出した心線間が湿潤し，この部分の漏洩電流の シュール熱やシンチレーションにより被覆が熱劣化 して充填剂の無機塩が分離析出し，これが吸湿して イオンに解離し，心線間で電気分解が起き水分が蒸 発して通電が途切れることが明らかになった。 そし て, 時間の経過と共に無機塩が䨌囲気中の水分を吸 収して電気分解が起き，この繰り返しによって心線 が電解侵食されることが確認された。この心線間で 無機塩の水分が蒸発する度に発生するシンチレーシ ヨンにより，被覆が次第にグラファイト化し発火し たものと考えられた。

防火造作業所の天井付近から出火した事例が報告 された47)。この作業所においては，作業所壁体に動 力用と電灯用の F ケーブルを梁にステップルで固 定していたが，このステップルが Fケーブルの心 線を損傷していたため, 経年劣化により発熱し, 線 間短絡を起こして出火したと判定された．ステップ ルによる F ケーブル心線の損傷が原因と判断した 同様な出火事例も報告された2)。また，ネズミによ 


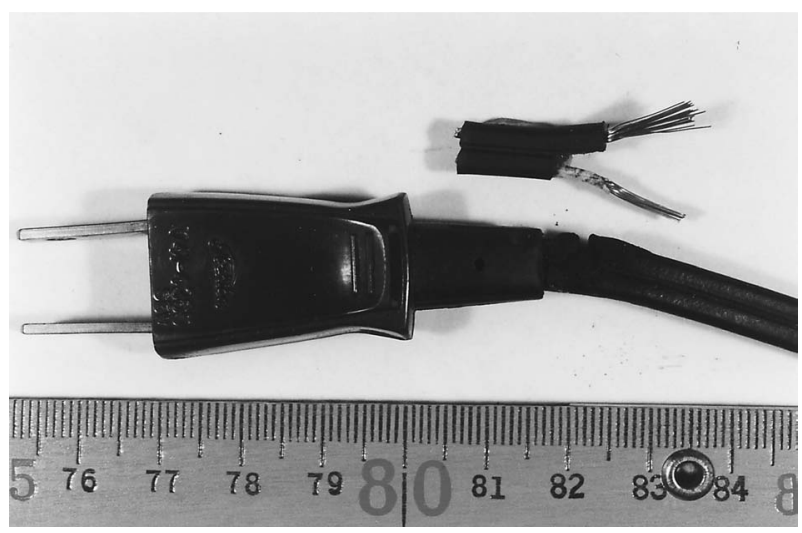

Fig. 3 Evidence of a small fire.

Chloroplene rubber code which was used for an electric heater $100 \mathrm{~V} 400 \mathrm{~W}$ was ignited at the root of an attachment plug.

る F ケーブルや平形ビニルコードの絶縁被覆の損 傷が原因と判断した出火事例が報告された ${ }^{48,50,51)}$.

電気ストーブ用電源コードの差込プラグ付け根部 分が，無理な曲げ力を頻繁に受けたために半断線と なって発熱し，トラッキング現象を起こしてボヤ火 災を生じた事例を Fig. 3 に示す.

\subsection{2 配線器具類からのトラッキング火災事例}

テーブルタップに打けるトラッキング破壊が火災 発生の原因となったと判定した事例が報告され た 26)。これは，ある会社の事務室の机の上から出火 した事例で，この机の上には $800 \mathrm{~W}$ のコピー機が 1 台置いてあり，これの電源は机上のテーブルタップ から取っていた．現場調查の際，テーブルタップに 入っているはずのコピー機の差込プラグは，両刃と も根元の位置で完全に溶断して横に転がっていた. また，差刃の先の部分はテーブルタップの刃受に融 着していた．さらに，差込プラグと接するテーブル タップの受口部分のフェノール樹脂が炭化してお り，この部分の抵抗值が数オーム程度になっていた

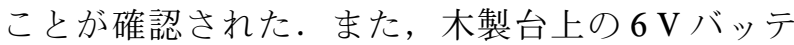
リーの充電器による充電中の出火事例が報告され た ${ }^{27)}$. 充電の際に，バッテリーの希硫酸液が木製台 上に一面にこぼれ，しかもバッテリー充電配線の端 子接続部が裸になっているのをそのまま使用してい たもので，裸の端子接続部 $\rightarrow$ 希硫酸液が浸潤された 木材 $\rightarrow$ 排水管の経路で漏電回路を形成し，木材が発
火することが再現実験により確認された。 また，低 圧屋内配線のジョイントボックス内で, 分岐接続部 が緩んで過熱し出火した事例が報告された ${ }^{47)}$.さら に, 差込プラグの多数の出火事例が報告されると共 に, 使用上, 規格 - 構造上, 保護協調上および保守 上の問題点が指摘された ${ }^{52}$.

一方，一般住宅においてもダウンライトが使われ るようなり，これからの出火事例が報告され た ${ }^{53,54)}$. ダウンライトというのは天井に埋め込む夕 イプの照明器具で，天井から吊り下げるタイプの照 明器具に比べて放熱が悪くなり易い構造となってい る. その上, 最近の建物には冷暖房の効率向上のた めに断熱材を使用することが多く，断熱材の誤使用 によるダウンライトの過熱事故の危険性が指摘され た。

屋外用映写装置のプリント基板の電源コネクタ部 分から出火した事例が報告された ${ }^{55)}$. この映写装置 は沢山のディスプレイユニットで構成されており， ディスプレイユニット間の防水措置が十分ではなか った。 そのため，隙間から雨水が浸入し，背面プリ ント基板の電源コネクタ部分でトラッキング現象を 起こして出火したものと判定された。 また, 電気冷 蔵庫の始動リレーに雨水が浸入したため, コードの 接続端子部でトラッキング現象を起こし, ボヤ火災 となった事例を Fig. 4 に示す.

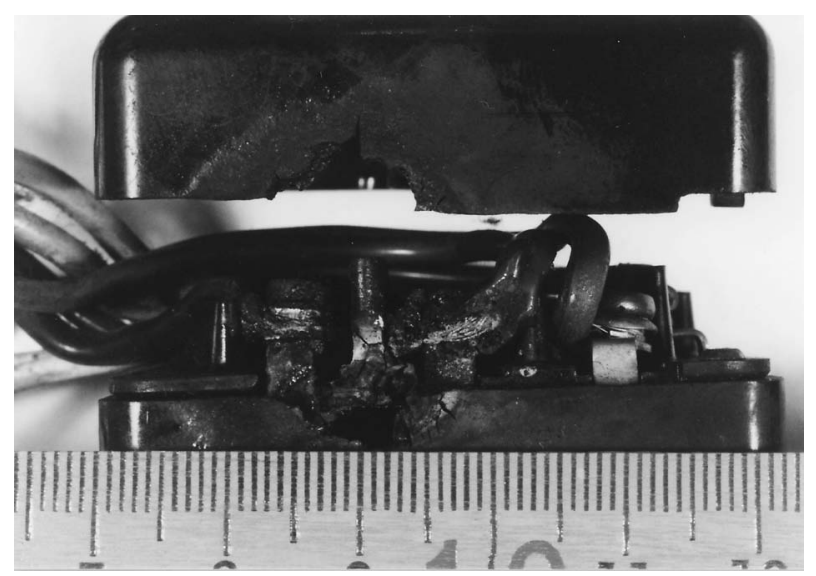

Fig. 4 Evidence of a small fire.

Phenol resin, starting relay case of an electric refrigerator, was ignited at the point of code's connecting terminal. 
スイッチ類の可動接点部分では, 開閉の際に電気 火花が発生する. 一般にこの電気火花は局部的に数 千度の高温状態となり, 接点部分の有機絶縁材料が 電気火花に曝されて熱劣化を起こす危険性がある. これに関連した写真現像室の照明用タンブラースイ ッチからの出火事例が報告された ${ }^{25)}$ 。これは, ある 研究所の写真現像室の鉛張りの流しの前面に取り付 けられた埋込型タンブラースイッチからの出火で, 発見が早かったためにボヤ火災で済んだものであ る.このスイッチは約 6 年半前に設置され, 現像作 業中はかなり頻繁に使用されていた。真鍮性の力 バープレートはレバーに接する箇所が一部溶融して おり，カバープレートを外してみたところ，スイッ チのフェノール樹脂絶縁材が炭化し，この部分の抵 抗值が数オーム程度になっていることが確認され た。 またここのスイッチのレバーが ONの位置で しかも片側だけが極端に炭化していたことから，タ ンブラースイッチの端子 $\rightarrow$ ェノール樹脂の炭化導

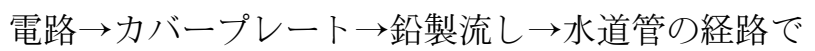
漏電回路を形成し, フェノール樹脂の炭化導電路の 部分が発熱点となっていたことが明らかにされた。 さらに，ネオンサイン用プルスイッチからの出火事 例が報告された ${ }^{26)}$. これは, あるキャバレーで発生 したもので, 閉店後に支配人がネオンサインの電源 をプルスイッチで切り，そこを立ち去るとまもなく そのプルスイッチが然えだしたが，支配人が気付き 注水消火したものである. そして，このスイッチの 炭化したフェノール樹脂絶縁材の抵抗值が数オーム 程度となっていることが分かった。このプルスイッ チを切るときに発生する火花でその部分の絶縁物が 炭化して出火することが再現実験により確認され た.

大型トラックのバッテリースイッチからの出火事 例が報告された ${ }^{56)}$. 瀬戸内海を航行中のフェリー ボートで火災が発生し, 海水による注水消火が行わ れた，その後の調査により，甲板上の大型トラック のバッテリースイッチのフェノール樹脂絶縁材の炭 化焼損抢よびその端子の溶融が明らかになったこと から，この部分がトラッキング現象を起こして出火 原因となったとする意見と, 出火原因は別にあった と主張する意見とが対立した. 後者の意見は, 海水
による冠水の再現実験によりかなり短時間でも絶縁 破壊が起こることが確認されたことから，バッテ リースイッチからの出火は二次的に起こったという ものである。これに関連した研究として，車両火災 の注水消火後, バッテリーが接続状態で放置した場 合の実験が行われており，再燃焼の危険性が指摘さ れた ${ }^{57)}$.

\section{2 原因究明}

火災の発生原因調査の時点において, 出火原因が トラッキング現象によると思われる場合，現場にお ける調査および採取した資料の検査・分析などによ る出火原因の究明には大きな困難を伴うことが予想 される，なぜなら，トラッキング現象を起こすのは 有機絶緑材料であり，これらは全て可然物であるた め, 証拠となるものが焼失してしまっている可能性 を否定できないからである，幸いにして焼失を免れ て資料が採取された場合でも，その資料から直接的 に出火原因を解明することは非常に困難なのが現状 と言える.したがって, 出火原因の究明に当たって は，火災時の目撃証言などを参考にして出火現場に おける柱などの残焼物の焼損形態の綿密な調査結果 および出火現場から採取した資料の検査・分析結果 など，あらゆる角度から収集した資料の分析結果な ぞを基に総合的に判断して出火原因の判定を行うの が定石となっている，この場合，先ず行う必要があ るのは，その資料が出火原因となったもの，すなわ ち一次的原因資料かあるいは他の原因によって発生 した火災により二次的に生成された資料かを判断す ることである。これについては, (1)資料の遊離炭素 に着目した識別 ${ }^{58)}$, (2)資料の溶融痕への炭素の巻き 込久に着目した識別 59-61), (3)資料の溶融痕内の気孔 の形態に着目した識別62)，(4)資料の酸化組織の酸素 濃度とDAS（樹枝状結晶の二次枝間隔, dendrite arm spacing）に着目した識別63)が報告された。(1) については, 有機絶縁材料のトラッキング現象によ り生成される導電性の遊離炭素に着目した。そし て，これが絶縁破壊の主体と考え，かつ，火災熱に よっても導電性を有する場合には遊離炭素の生成が 介在していると考えた．この遊離炭素については， $\mathrm{X}$ 線回折装置により，各条件下に打歪成物の 回折パターンを測定して比較検討を行った。 その結 
果, 生成の際の加熱条件による変化をよく示し, ト ラッキング生成物と火災熱による生成物との識別が 可能なことを明らかにした。 (2)については, ビニル コードの銅線の溶融痕への炭素の巻き込久の有無を $\mathrm{X}$ 線マイクロアナライザを用いて分析を行うこと により，一次痕・二次痕の識別が可能な場合のある ことが報告された ${ }^{59)}$. また，ビニルコードの銅線の 溶融痕への炭素の巻き込久の有無を金属顕微鏡およ び走査型電子顕微鏡などを用いて調べると共に，巻 き込まれた炭化残渣中の炭素の結晶構造を顕微ラマ ン分光分析装置を用いて分析を行うことにより，一 次痕・二次痕の識別が可能な場合のあることが報告 された ${ }^{60,61)}$. (3)については, 電線の短絡時にガスの 巻き込久現象が起こって資料内に気孔ができるが, 一次痕と二次痕では気孔の形成過程が異なるために 気孔の形態に違いが生じることに着目した。これま でに数多くの研究が行われてきており，一次痕・二 次痕の識別が可能な場合のあることが報告された。

(4)については，ビニルコードへの溶融痕の生成時の 雾囲気温度を推定するすることにより，一次痕か二 次痕かの判定が可能なことに着目した。そして, 酸 化組織の DAS と酸素濃度の測定を行った。その結 果, 溶融痕生成時の䨌囲気温度が推定でき，それに よって一次痕か二次痕かの判定が可能な場合のある ことを明らかにした。

一方，トラッキング火災の原因究明には，(1)現象 (過程）の解明々，(2)資料の検査・分析手法の開発 が必要である. (1)現象 (過程) の解明は, 電気器具 などに抢けるトラッキング現象のメカニズムを解明 することであり，これは火災現場における調査の進 め方に寄与する. (2)資料の検査・分析手法の開発 は，火災現場から採取される物的証拠資料を検査・ 分析することにより，出火原因を明らかにする手法 を開発するものである。これは理想的には，先ずあ

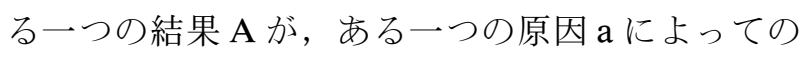
み起こるような因果関係を発見することである，次 にこの関係を応用して, 火災現場から結果 A を得 ることにより，その出火原因 $\mathrm{a}$ を特定する手法を開 発することである。しかし，実際には，ある一つの 結果が，複数の原因によって起こったり，あるいは 複数の結果に対して複数の原因が複雑に対応してい
るのが通常である.したがって, 時間的な前後関係 も考慮しながら, 複数の結果を基にある一つの原因 を絞り込むことが必要となる。そして，このような 手法の開発は, 出火原因の判定に寄与することにな る.

これまでに, 加熱による絶縁劣化などを調べるた め, 木材やポリ塩化ビニルなどの炭化温度と電気抵 抗の関係などについて研究が行われているが, 試料 を高温度に加熱した状態で測定が行われているの で，火災が鎮火したあとで採取された炭化状態の資 料の特性をそれらから推定することができなかっ た。 そこで, 実火災を模擬する加熱特性を持った電 気炉を用いて有機絶縁材料を加熱炭化させ, 炭化物 の電気的特性に及ぼす形成温度の影響についての検 討を行った ${ }^{64)}$.さらに, 火災現場で採取した電線や 配線器具類には, トラッキングなどの現象が起こっ たことを示す痕跡が残っていることがあり，これら の痕跡の生成原因が判明すれば，出火原因を究明 . 立証する上での重要な手掛かりとなることが考えら れた。一般に, 有機物を加熱すると, 最終的には Fig. 5 に示すようなグラファイトという名の六方晶 形の結晶となり，このようなグラファイトと無定形 炭素との間は連続的であって, 各段階の炭素が存在 する65). そして, グラファイト化の程度は, X 線 回折装置によって結晶の(002)面の面間隔を測定す ることにより知ることができると考えられた。 そこ で, 様々な温度で加熱生成した有機絶縁材料炭化物 に対して，X線回折装置によってグラファイト化 の程度を明らかにするため結晶構造の解析を行っ た。この一例を Fig. 6 に示す. また, 走査型電子 顕微鏡により, Fig. 7 に示すような形態観察を行っ た.そして,これらの結果を基に, 炭化物の結晶構 造の变化に及ぼす形成温度の影響についての検討を 行った. その結果, 有機絶縁材料の炭化生成物の形 成温度の究明には, 抵抗率の測定が有効なことが明 らかとなった。 また, X 線回折装置によって有機 絶縁材料の炭化生成物の結晶構造の解析を行うこと により，トラッキング現象が存在したことの立証が 可能な場合があり, 出火原因の判定に役立つことが 明らかとなった66).

従来から耐トラッキング性試験が行われて, 沢山 


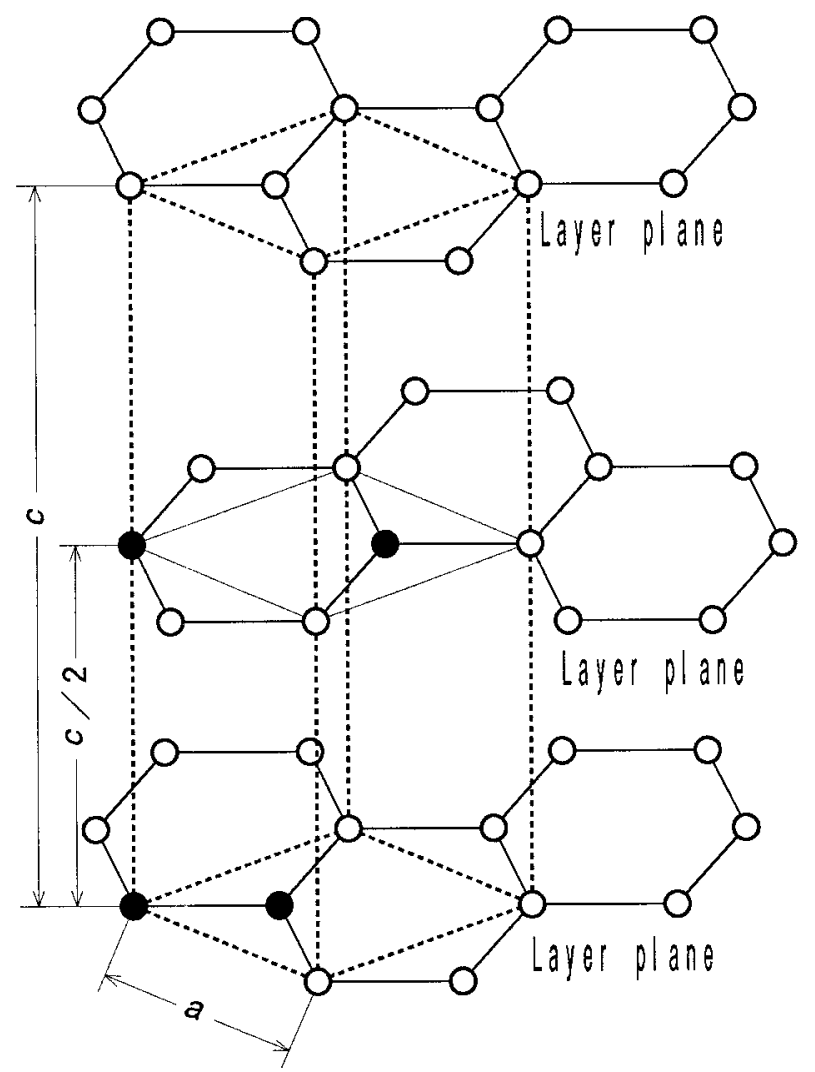

Fig. 5 Hexagonal crystal lattice of graphite ${ }^{65)}$.

The dashed lines indicate a unit cell. $a, c$ : Lattice constant $(a=2.461 \AA, c=6.708 \AA), c / 2$ : distance between the layer planes $(d=c / 2=3.354 \AA)$.

の試験データが報告されている。しかし，耐トラッ キング性と着火危険性との関係については明確にさ れて抢らず，両者の関係の解明が必要とされてい た. そこで，耐トラッキング性の試験データを火災 原因調査に有効に活用できるようにするため, 各種 材料を用いて, 耐トラッキング性試験の結果と火災 危険性との関係の解明が行われた。 また，耐トラッ キング性試験結果との相関関係ができるだけ簡単に なるような火災危険性の評価試験法の検討が行われ た 67,68$)$.

なお， 日本では電気的な着火のメカニズムの解明 が多くの研究機関や大学において取り上げられ, 長 期間に亘って研究が行われてきているが，米国では ほとんど取り上げられていないことが指摘されてい る69). また, 電気配線類からの出火のメカニズムの 解明に関する論文が米国の研究機関や大学からほと

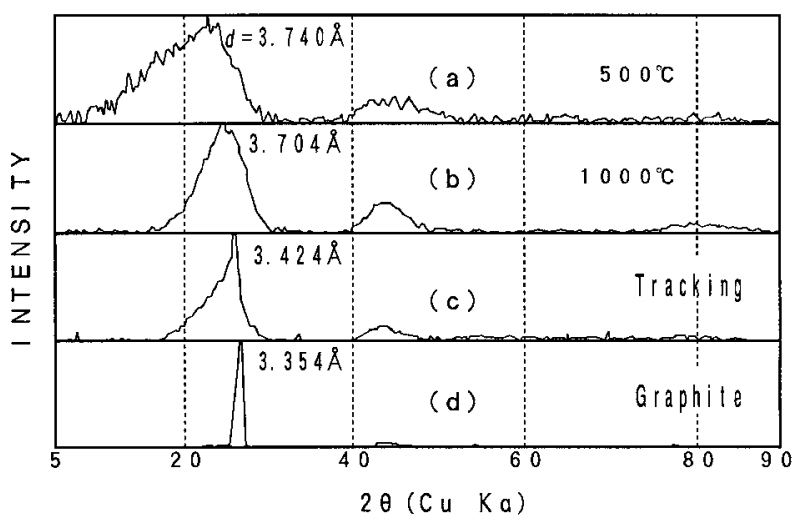

Fig. 6 Profiles of (002) diffraction for carbonized phenol resin.

They show the results of analyzing the crystal structure for carbonized phenol resin by X-ray diffraction. $d$ : Surface distance corresponding to 002-surface for the sample, layer plane distance, $d=\lambda /(2 \sin \theta) ; \lambda$ : wave length of $\mathrm{X}$-ray, $\theta$ : diffraction angle. (a) $500^{\circ} \mathrm{C}$, (b) $1000^{\circ} \mathrm{C}$, (c) tracking, (d) graphite.

んど出ていないことが指摘されている.

\subsection{1 配線類}

クロロプレンゴムコードは耐熱性がよく，ヘアー ドライヤーや電熱器などのコードとしてよく用いら れている．また，このゴムも Fケーブルの絶縁被 覆に使われるポリ塩化ビニルと同様に塩素を含んで いるため自然性がないのを特徵としている。そし て，これの絶縁破壊による発火について報告され た ${ }^{19)}$. 先ず，クロロプレンゴムコードが半断線状態 などにより異常過熱が起こった場合を想定し，加熱 温度と時間を変えて加熱したクロロプレンゴムに対 して，加熱による抵抗率および重量の変化が調べら れた。 また，示差熱分析装置により分解熱の変化が 調べられた。そして，温度による抵抗率变化は 4 段 階に分かれていることが明らかにされた。さらに， X線回折抢よび電子線回折により絶緑体からグラ ファイトになる過程が詳しく調べられ，クロロプレ ンゴムコードの発火危険性の検討が行われた。 そし て，コードが $480^{\circ} \mathrm{C}$ 以上の温度であらかじめ異常過 熱される場合に発火危険性のあることが明らかにさ れた。

ポリ塩化ビニルは F ケーブルの絶縁被覆材とし 

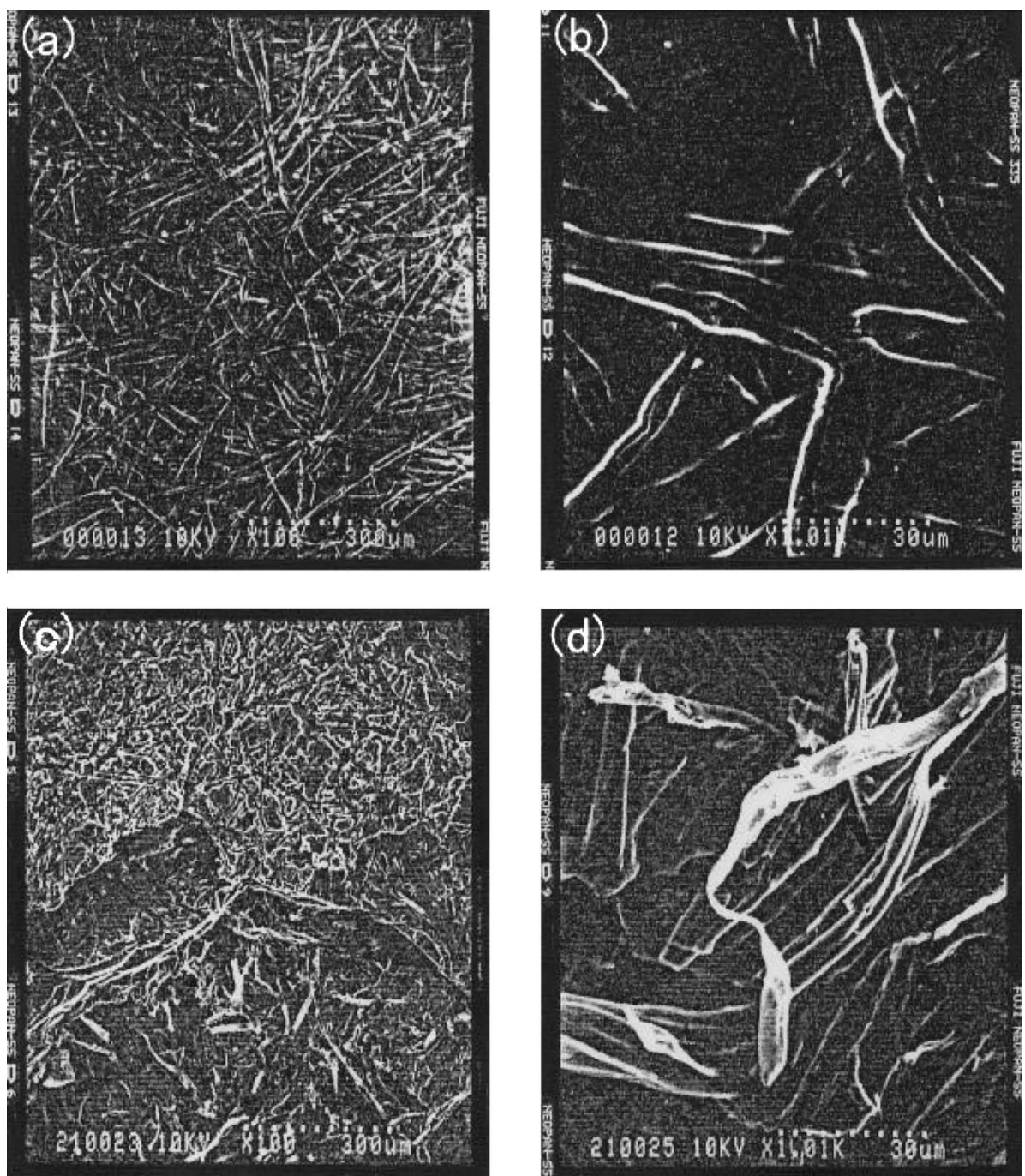

Fig. 7 Electron microphotography for carbonized phenol resin.

(a) $600^{\circ} \mathrm{C}, \times 100$; (b) $600^{\circ} \mathrm{C}, \times 1000$; (c) $1000^{\circ} \mathrm{C}, \times 100$; (d) $1000^{\circ} \mathrm{C}, \times 1000$.

て広く使用されている．Fケーブルの絶縁層および シース層のポリ塩化ビニルとしては純粋なプラスチ ックスが使用されることはまれで, 塩化ビニルモノ マーの他に可塑剂, 安定化剂, 難燃化剂の他に各種 の充填剤が配合されている。このような Fケーブ ルを屋外で使用した場合，これの接続部付近では雨 水で生じた水膜を通して漏洩電流が流れ，トラッキ ング現象を生じることがある2,45)。そこで，Fケー ブル中に配合されている各種の混和剤の耐トラッキ ング性に及ぼす影響と着火機構の究明の研究が行わ れた ${ }^{20,21)}$. 先ず，F ケーブルを試料とし， IEC 耐ト ラッキング性試験法に準じた装置により実験が行わ
れた．その結果，アークが発生した時だけ電流が半 波の整流波形となることが明らかにされた。そし て, このアークの発生原因は, 絶縁層部分に形成し た遊離炭素と心線との間に形成される乾燥帯の幅が 狭くなり，両者間の電界が局部的に強くなることに よるものと考えられた。このアークが数回繰り返し 発生して最終的にシース層が着火して扣り，トラッ キング破壊だけとなる場合は着火源となるアークが 発生していなかった.アークが発生しない理由は, F ケーブル端末から心線方向へ進行した炭化残渣中 に電解液が残留し, 乾燥帯が形成されないためと考 えられた. 次に，Fケーブルと同じ種類および類似 
配合量の混和剤を配合したシート状試料について, 試験電圧とアークの発生との関係および試験電圧と 着火との関係が調べられた。そして，各種混和剂の アークの発生と着火に及ぼす影響について検討が行 われた。

車両火災の初期消火には水を用いるとが多いが， 鎮火後に再燃することが問題となっていたことか ら，これについての実験が行われた ${ }^{57)}$ 。この実験で は，車両のエンジンルーム内を水で消火しても，し ばらくシンチレーションを繰り返した後に有炎燃焼 に移行し，再燃することが確認された。また，再燃 した部位の配線には溶融痕が認められたことから， 火災調査時に抢いて，発火原因の重要な手掛かりの 一つである溶融痕について，再然により二次的に生 じる溶融痕と一次痕との識別法の開発の重要性が指 摘された。

$\mathrm{F}$ ケーブルの絶縁被覆の損傷箇所への雨水などの 浸入による絶縁劣化が問題となっていたことから， 損傷部に電解液を滴下して実験を行い，絶縁劣化の 進行状況が調べられた $20,21,45,46,70)$ 。このうち F ケー ブルの発火機構については, 絶縁被覆がグラファイ 卜化して発火する過程が報告された ${ }^{45)}$ 。また，発火 部の心線の放電痕跡抢よび絶縁被覆材の炭化生成物 の分析結果から，Fケーブルの発火現象と放電痕跡 との関連性などについて報告された ${ }^{70)}$ 。さらに，通 常の使用状態であっても，表面が電解性物質で污染 された場合, 微小放電を生じてポリ塩化ビニルが熱 劣化を起こし，塩化カルシウムが生成されることが 明らかにされた。そして，この塩化カルシウムが， 空気中の水分を吸収し，イオンに解離して再び電流 が流れ微小放電を生じて炭化が進行し，これらの繰 り返しによってトラッキング破壊に至ることが報告 された ${ }^{71)}$.

電線の素線の断線状態としては様々な状態が想定 される，そこで，最も過酷な 1 本の素線以外は全て 断線した状態での実験が行われた ${ }^{72,73)}$ 。 また, 器具 用ビニルコードが高温度のもとでしかも屈曲や引張 り力を繰り返し受ける状態で使用する場合, 発火焼 損することがあり，これの発火原因としては，ビニ ルコードの素線断線の結果, 残存素線の異常発熱に 基づくものの他に，ビニル被覆の高温劣化が発端
で，印加電圧によって熱暴走を起こし発火に至る々 考えられた。これは素線断線に伴う発熱や火花放電 あるいはアーク放電等によってビニル被覆の表面や 内部が局部的に異常発熱すると共に絶縁体が半導体 化して電流が流れ，さらに自己発熱が加わって発火 に進展するというものである．ビニルコードを実際 に使用するとき，この有機半導体化が短時間に，か つ容易に進行することは考えられないが，比較的高 温度のもとで長時間使用される場合には，ビニル被 覆の有機半導体化に伴う発火現象の可能性が予期し うる。そこで，これについての実験が行われ た ${ }^{19,74)}$.

\subsection{2 配線器具類}

電気器具には電気を供給するためのコンセントや 差込プラグが不可欠で，多数使用されている. しか も，これらの接続部は使っているうちに緩みなどを 生じて熱劣化をまねき易く，トラッキング現象も他 の部分に比べて起こし易い。 その結果, コンセント や差込プラグからの出火が配線器具の中で最も多く なっている31)。ところで，これまでに述べたよう に，絶緑材料単体や電線被覆に対する耐トラッキン グ性試験や絶縁破壊機構などについての報告は多 い.しかし，コンセントや差込プラグなどといった 成形品に対する発火機構などの検討を行ったよう な, 出火原因の究明に役立つ報告は比較的少な

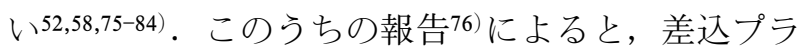
グ両刃間のトラッキングが火炎の発生原因と判定し た火災現場から採取した資料の分析およびトラッキ ング火災の再現実験が行われた。そして，差刃の間 の絶縁物上に導電性溶液または塵埃を含む水分など が存在したとき, 差刃が電極となってトラッキング 現象のメカニズムの項で述べたような経過をたど り，差刃の間の絶縁物上に炭化導電路を形成するこ とが明らかにされた。また，この過程において， アークで発生した熱により，差刃間の絶縁物が加熱 され，絶縁物の成分が気化して発火することが明ら かにされた．さらに，目視による差刃の付け根部分 における溶融痕の確認, 差刃間の絶縁物表面抵抗の 測定，絶縁物表面上から採取したサンプルの成分分 析による銅または亜鉛の存在の確認および使用環境 からの裏付けにより，トラッキング火災の判定が可 
能な場合のあることが明らかにされた。 また，市販 品のポリ塩化ビニル成形品の差込プラグを試料と し，これの熱劣化と吸湿による発火のメカニズムの 解明が行われた ${ }^{78-80)}$ 。そして，污損や湿潤のない使 用環境においても熱劣化させると，ポリ塩化ビニル の熱分解時の反応で吸湿性の強い塩化カルシウムが 生成され，通電停止後にこの差込プラグを自然放置 あるいは自然放置と再通電を繰り返した場合には, 生成された塩化カルシウムの吸湿により絶縁抵抗が 低下することが明らかにされた。 また，このような 熱劣化と吸湿により試料の表面または内部で放電が 発生し, 炭化導電路を形成して発火することが明ら かにされた。ささらに，差込プラグとコンセントとの 接続部における接触不良による熱劣化と発火に至る メカニズムの解明が行われた ${ }^{81-83)}$ 。この実験には, 市販品のポリ塩化ビニル成形品の差込プラグと尿素 樹脂成形品のコンセントを用い，コンセント刃受の 保持力を変えてプラグの温度と接触抵抗の測定が行 われた。 そして，通電電流がある大きさを超える と, プラグとコンセントの接触不良による出火危険 性が急激に高まることが分かり，火災現場での調査 の際に，プラグとコンセントの接続部からの出火と 思われる場合には，これへの負荷の接続状態および 使用状況の判明の重要性が指摘された.

\section{4. トラッキング火災防止対策}

ここでは電線やケーブルに抢ける，トラッキング 火災の発生を防止するための対策について述べる。

このような防止対策としては，(1)絶縁材料の特性を 改良すること，(2)適正な絶縁材料を使用すること， (3)施工方法の改善により延焼防止策を講じること, (4)有機絶縁材料を難燃材で保護すること，(5)トラッ キング現象の発生を検知して電源を遮断する装置を 設置すること，などが挙げられる.

(1)については，直接的な対策と間接的な対策があ る. 直接的な対策としては, 耐トラッキング性の優 れた全く新しい材料の開発および既存の材料への各 種添加剂の配合により特性を改善することが挙げら れる ${ }^{84)}$ 。一般に不活性無機物質を材料に配合する と，乾いた状態での耐アーク性が向上し，耐トラッ キング性も向上することが多い6)。しかし，湿った
状態での耐トラッキング性は充填剂の種類, 粒度, 配合量によって異なり, 特にシリカ配合の場合は, ある配合条件下ではかえって耐トラッキング性が低 下する場合のあることが指摘された ${ }^{43)}$. 一方, 間接 的なものとしては，代表例として鼠対策が挙げられ る. 従来から配線の絶縁被覆材が鼠にかじられる被 害が問題となって抢り，防止対策がいろい万と試み られている51).

(2)については，トラッキング現象を起こしにく く, しかも燃焼しにくい絶縁材料を使用することで あり，無機絶縁材料の使用が最も効果的である.し かし, 無機絶縁材料は有機絶縁材料に比べて, 加工 性, 柔軟性が著しく劣るため, 高温雾囲気中での使 用などの特殊な場合を除いて, 電線類には有機絶縁 材料を使用せざるを得ない状況である. 有機絶縁材 料の特性向上のための研究は絶えず行われており, 使用目的に応じて適正に使用する必要がある ${ }^{85,86)}$.

(3)については, 特にグループケーブルの場合に重 要であり, 燃焼性状の評価試験と並行して各種施工 方法の改善が行われている ${ }^{86-88)}$.

(4)については, 特にグループケーブルの敷設工事 の際に, ケーブルを被覆している有機絶縁材料を保 護するため，無機不燃性繊維などの吹き付け塗布な どの対策がとられている87).

(5)については，Fケーブルを用いた配線が多用さ れていることから，Fケーブルのトラッキングの発 生原因の究明と事故防止装置の開発が行われてい る.この装置は Fケーブルに㧍いて, トラッキン グ現象の進行に伴って, 絶縁材料の表面に形成した 炭化導電路を流れる電流の波形の幅と波高值が増大 すると共に, 最終的には半波整流波形および歪んだ 交流波形を示すアーク放電電流が発生することを検 知して電源を遮断する仕組みとなっている89,90)。 た, 従来の保護ブレーカに高速高限流機能（高速で 開極して接点を開くと共に, 消弧室でのアーク分割 により事故電流を制限する機能）を持たせた改良が 行われ, 実用化されている ${ }^{91-93)}$. さらに, 一般家屋 などにおいて, トラッキング現象の発生をコンセン トの表面に流れる $5 \mathrm{~mA}$ 程度の微弱電流により検知 して，電源を遮断する機能を持たせた特殊なコンセ ントが開発されている ${ }^{94)}$. また, ビルなどのケーブ 
ル線路において, 異常な温度上昇を検知して電源を 遮断するための感知器が開発されている.これには ディジタル型とアナログ型があり, ディジタル型に は感知線型とチューブ型がある ${ }^{95)}$.

材料の特性や施工方法の改善とそれを評価するた めの評価試験法とは車の両輪のような関係にあり, 両者の研究開発はユーザーとメーカーが協力しつつ 並行して行う必要がある。そして，そのためには メーカー側のデータの公表が望まれる. また, ユー ザーの側も，使用材料選定の際にこれらのデータを 十分に活用することが望まれる.

\section{5. 将来の課題}

これまでに公表されているトラッキング火災事例 を取り上げて紹介したが，このような事例は，火災 という代償を払って得られた貴重な知的財産とも言 えるものである。そして，それらの收集事例が少な いうちは書類の形で分類整理しても余り問題ない が，收集事例が数百数千ともなると，必要とする事 例を抜き出して活用するには多大な労力を費やすこ とになる，そこで，これらの火災事例の合理的な活 用法として，火災事例データベースとしてコンピ ュータに登録しておくことが考えられるそそして, 必要に応じてキーワードにより火災事例データベー スを検索して活用できるような体制の整備が切望さ れる. 現在のところ，一部でしかも不十分ではある が，コンピュータによる火災事例データベースの活 用が試みられている ${ }^{96-99)}$.

トラッキング火災の原因究明には, 現象の解明々 資料の検査・分析手法の開発が必要であり, 配線類 および配線器具類でのトラッキング現象 (過程) の 解明および，火災現場から採取される物的証拠資料 の検査. 分析による, 出火原因の解明手法を取り上 げて紹介した。そして, 電気器具などにおけるトラ ッキング現象のメカニズムについては, 除々に解明 されて来ていることを明らかにした。 また，X線 回折装置によって有機絶縁材料の炭化生成物の結晶 構造の解析を行うことにより, トラッキング現象が 存在したことの立証が可能な場合のあることを明ら かにした．さらに，目視による差込プラグの差刃の 付け根部分における溶融痕の確認, 差刃間の絶縁物
表面抵抗の測定, 絶縁物表面上から採取したサンプ ルの成分分析による銅または亜鉛の存在の確認およ び使用環境からの裏付けにより，トラッキング火災 の判定が可能な場合のあることなどを明らかにし た。今後は，火炎現場から採取される資料から出火 原因へと結びつける検査・分析手法の開発が切望さ れる.すなわち，資料の検査・分析によって得られ る複数の結果をもとにある一つの原因を絞り込む手 法の開発が切望される。ささらに，ある一つの結果が ある一つの原因によってのみ起こるような因果関係 を発見し，この関係を応用して，出火原因を特定す る手法の開発が切望される.

トラッキング火災の判定手法などを取り上げて紹 介したが，これらの研究には，示差熱分析装置，顕 微ラマン分光分析装置, 走査型電子顕微鏡, $\mathrm{X}$ 線 回折装置およびX 線マイクロアナライザなどの高 性能な装置が使用されている。 また，火災現場から の採取資料についても，これらの装置を活用して鑑 定および検査が行われている。しかし，その資料を 収集する火災現場調査の段階において使われる, 科 学的な装置や器材はほとんどないのが現状であ $る^{100)}$.

この主な原因として，(1)携帯性，(2)環境条件，(3) 費用対効果が挙げられる。(1)の携帯性については, 現場で使うためには装置や器材を小型, 軽量で, 振 動や衝撃にも強くする必要があり, 特注品となる. (2)の環境条件についても, 装置や器材を厳しい温 度，湿度，塵埃抢よび污れに耐えるようにする必要 があり, 特注品となる。(3)の費用対効果について は, 装置や器材の使用頻度, 現場に抢ける原因究明 の重要度およびそれの使用による原因判明の可能性 とそれに要する費用（導入費，維持管理費）との関 係が検討対象となる。 また，これは火災以外の事故 や事件の原因究明の費用対効果と比較される相対的 なものであり，火災の場合には，分析結果が原因判 明の手掛かりを得るだけに留まることが多く，他の 分野に比べて費用対効果が低くなりがちとなる。 た，火災現場で使うためには装置や器材が特注品々 なり，市販の高性能な装置をそのまま導入して使え る場合と異なり，費用対効果をさらに低くしてしま いがちとなる。しかし，社会公共に及ぼす影響が大 
きく, 貴重な財産を焼失させ，尊い生命をも奪って しまう火災の原因究明を，迅速的確に行うことは極 めて重要である.

現場調査の段階でこれらの高性能な装置や器材を 使用できれば，その場で分析結果が得られ，それを 直ぐに調査方針にフィードバックすることができ， 迅速的確な火災原因の究明に大きく寄与することに なる，そのためには，資料を収集する火災現場調査 の段階においても使用できる, 科学的な装置や器材 の開発および導入が切望される．このような装置と しては，携帯型と移動型とが考えられる．前者につ いては，小型軽量にするため開発に大きな困難が予 想されるが，後者については，現在実験室などで使 われているものを耐震性などを改善して專用の車に 搭載することで可能となり, 前者に比べて開発が容 易と考えられる.

さらに，現場での調査を能率的かつ的確に行うた め, ウェアラブルコンピュータ101,102)を装備するこ とが考えられる.これは, 服やカバン, 腕時計のよ うに身につけて（wear）利用するコンピュータで, 操作は主に音声によって行うようになっている. 透 過型ヘッドマウントディスプレイを表示装置にした ポケットサイズの超小型パソコンなど，様々な技術 が研究されている.ヘッドマウントディスプレイ付 きの小型パソコンや，デジタルカメラを組み込んだ 腕時計, 携帯情報端末の機能を持った腕時計などは 既に製品化されている.この技術は，航空機の整備 の際に, 整備現場と整備マニュアルなどの保管場所 との間を整備士が頻繁に行き来していることにヒン トを得て開発されたと言われている。これにより， 整備士が整備現場を離れることなく，必要な情報を 得ることができるようになることを目指している. 火災現場調査に抢いても, 出火原因の究明を行う者 がこれを装備することにより，調査を行いながら火 災事例データベースを活用することも可能になると 考えられる，そのためにも，火災事例データベース をさらに充実させる必要がある。 また, 調査を行う 者は, 音声による操作のおかげで両手が自由に使え るようになり, 焼損状況の記録, 写真撮影記録, 寸 法計測記録および必要データの検索・取り出しなど を自由に行うことが可能になると考えられる。この
ように, ウェアラブルコンピュータの装備は, 迅速 的確な火災原因の究明に大きく寄与することになる ものと期待される.

\section{6. おわりに}

火災の原因究明においては, 火災現場の証拠物件 だけから出火原因を判定するのは危険である. 綿密 な現場における調査データ，物的証拠資料および人 的証拠資料に基づいて始めて的確な原因判定が可能 となる.したがって, 出火原因の究明は事例の積み 重ねが重要視される分野でもあり, 厳しい制約の基 ではあるが，これまでにトラッキング火炎事例が公 表され，火災鑑定や再発防止などに活用されてい る.しかし，それはほんの一部で，そのほとんどが 活用されていないように思われる。これらの貴重な 鑑定事例は，火災原因調査に有用なことは勿論, メーカの安全対策などにも大いに活用できるものと 考えられる. 日本鑑識科学技術学会発足準備の段階 において, 部会のような形で事例発表の場を設ける 構想もあったが，まだ実現していない。本学会によ り, 眠っている貴重な鑑定事例を掘り起こし, 火災 事例データベースとして整備されるようになること を切望する。

また，火災現場からの採取資料に対して，分析な どのために様々な高性能な装置を使用して鑑定・検 查が行われている. しかし，その資料を收集する火 災現場調査の段階において使われる, 科学的な装置 や器材はほとんどないのが現状である. 現場調査の 段階でこれらの高性能な装置や器材を使用できれ ば, 迅速的確な火災原因の究明に大きく寄与するこ とになる，そのためには，資料を収集する火災現場 調査の段階においても使用できる, 科学的な装置や 器材の開発抢よび導入が切望される. さらに, 火災 事例データベースなどの必要な情報の検索・取り出 しなどを，火災現場において自由に行うことが可能 になると考えられ, 迅速的確な火災原因の究明に大 きく寄与することが期待される, ウェアラブルコン ピュータが装備されることを切望する.

\section{文献}

1）吉村 昇, 西田 眞, 能登文敏: 有機絶縁材 
料の耐トラッキング性. 静電気学会誌, 6, 7279 (1982).

2）青池 晃：トラッキング現象とその問題点に ついて。炎災, 30(3), 15-26 (1980)。

3）東京消防庁予防部予防課：平成11年中に発生 した電気火災の概要。電設技術 (12), 123-129 (2000).

4) http://www.fdma.go.jp.

5）能登文敏：コンデンサの間欠放電による耐卜 ラッキング性試験について. 電学誌， 82, 559566 (1962).

6) 能登文敏：最近の絶縁材料試験法. 電学誌, 88, 802-811 (1968).

7）池尻忠夫：内部にも多量の水分を含む湿潤絶 縁物面上のトラッキングの特異性とその機構. 電学誌, 88, 1869-1878 (1968).

8）斎藤省吾：高分子の電気的物性とその応用. pp. 206-222, 丸善, 東京 (1972).

9）絶縁材料耐トラッキング性試験法特別専門委 員会：電気学会技術報告（II 部）第115号 IEC -Publication 112による絶縁材料の耐トラッキ ング性試験方法, pp. 1-51, 電気学会 (1981).

10) IEC 112, Third edition (1979), "Method for determining the comparative and the proof tracking indices of solid insulating materials under moist conditions"'.

11）宮下隆雄 : 絶縁材料の耐アーク性. 静電気学 会誌, 6, 80-86 (1982).

12）三宅 彰, 瀬川 渡: 高分子の電気的性質. pp. 153-155, 培風館, 東京 (1982).

13）中村修平, 川井二郎, 家田正之, 沢 五郎: 臭素系難燃剂によるポリエチレンの難燃化と耐 トラッキング性. 電学論 A, 103, 103-110 (1983).

14）河村鴻允, 谷口敏幸, 能登文敏 : 防食効果を 考慮したプリント基板のトラッキング劣化保護 塗料に関する研究. 電学論 A, 106, 131-138 (1986).

15）電気学会 : 電気工学ハンドブック. pp. 277278, 電気学会, 東京 (1988).

16）田中祀捷：V. 絶縁材料. 電学論 A, 110, 44
-48 (1990).

17）電気学会放電ハンドブック出版委員会編 : 放 電ハンドブック. pp. 459-472, オーム社, 東 京 (1995).

18）平井平八郎, 豊田 実, 桜井良文, 犬石嘉 雄 : 現代電気 - 電子材料. pp. 15-18, オーム 社, 東京 (1996).

19）金原寿郎：加熱によるコード被覆の絶縁劣 化. 火災, 28(6), 10-15 (1978).

20）河村鴻允, 佐藤忠雄, 能登文敏 : 湿潤污損下 に括ける塩化ビニール樹脂のトラッキングと着 火現象. 日本火災学会大会学術講演梗概集, 13 -16 (1978).

21）河村鴻允, 能登文敏 : 湿潤污染下における塩 化ビニル樹脂の耐トラッキング性と着火現象.

電学論 A, 98, 579-585 (1978).

22）名古屋市消防局消防研究室: 電気火災調査要 領. pp. 15-17, 全国加除法令出版, 東京 (1986).

23）東京消防庁予防部調査課：火災調查技術教本 第 3 巻. pp. 5-55, 東京防災指導協会, 東京 (1987).

24）東京消防庁: 新火災調査教本第 3 巻電気火災 編。pp. 18-64, 東京防災指導協会, 東京 (1999).

25）木村金造，萩原隆一：電気器具に現れた金原 現象 2 例. 火災, 11(3), 250-253 (1961).

26）一倉伊作 : 電気器具からの発火について一金 原現象による発火一。炏災, $11(3), 245-249$ (1961).

27）細井三郎, 前田賢二, 大西一雄 : 金原現象の 応用について。科警研報告， 14, 122-125 (1961).

28）菊池光一, 吉村 昇, 能登文敏 : 木材の漏れ 電流による炭化現象と発火機構. 電学論 A, 104, 517-524 (1984).

29）菊池光一, 吉村 昇, 能登文敏 : 木材の交流 トラッキングによる発火現象. 電学論 A， 105, 573-580 (1985).

30）小林義和, 吉村 昇, 西田 眞, 能登文敏, 菊池光一: 木材の表面に打電気的発火現 
象. 電学論 A, 107, 446 (1987).

31）小林義和，吉村 昇：木材の電気的発火現象 に及ぼす環境の影響. 日本火炎学会研究発表会 概要集, 91-92 (1990).

32）吉村 昇, 西田 真, 能登文敏 : 霧による有 機絶縁材料表面のぬれとその放電開始に及ぼす 影響. 応用物理，47, 538-546 (1978).

33）西田 真, 吉村 昇, 能登文敏 : 霧でぬれた 有機絶縁材料表面のトラッキング破壊．電学論 A, 99, 121-127 (1979).

34）河村鴻允，能登文敏：紙基材フェノール樹脂 のトラッキングに抢ける溶出金属の影響. 電学 論 A, 98, 439-445 (1978).

35）河村鴻允，坂本三郎：電解液一紙基材フェ ノール樹脂積層板界面における溶出金属の挙動 とトラッキング現象．電学論 A, 101，633-640 (1981).

36）河村鴻允，谷口敏幸，坂本三郎：電食による 銅金属化合物の増殖現象と絶縁物の劣化. 日本 火災学会論文集，32，9-18（1982）。

37）河村鴻允，能登文敏 : 紙基材フェノール樹脂 のトラッキングに抢ける溶出金属の影響. 電学 論 A, 98, 439-445 (1978).

38）河村鴻允, 能登文敏, 菊池光一 : 直流による 紙基材フェノール樹脂積層板のトラッキング現 象. 電学論 A, 100, 415-422 (1980).

39）中村修平, 川井二郎, 沢 五郎, 家田正之 : ポリエチレンの塩素化と耐トラッキング性. 電 学論 A, 102, 287-294 (1982).

40）能登文敏：エポキシ樹脂の耐トラッキング 性. 電学誌, 81, 1625-1632 (1961).

41）能登文敏：エポキシ樹脂の耐トラッキング性 に抢よぼす硬化剂と充填剤の影響。電学誌,

82, 209-218 (1962).

42）鴨沢勅郎, 吉村 昇, 西田 真, 能登文敏, 外井正義：エポキシ樹脂のトラッキング劣化に 及ぼす紫外線の影響．電学論 A，108，397-404 (1988).

43）熊谷誠治, 王 新生, 吉村 昇: 屋外用エポ キシの耐トラッキング性に及ぼす熱老化と吸水 およびそれらの重畳効果. 電学論 A, 118, 1255
-1263 (1998).

44）柏谷一弥編：法科学シリーズ(2)捜査のための 法科学. pp. 48-66, 令文社, 東京 (1983).

45）木下勝博，萩原隆一，金原寿郎：漏電による F ケーブルの発火危険性. 火災, $28(3), 30-37$ (1978).

46）横浜市消防局計画課：火災発生事例. 火災, 40(1), 60-61 (1990).

47）東京消防庁予防部調査課：屋内配線における 電気火災．火災，46(2)，6-12（1996）。

48）海蔵寺明治, 西嶋靖治, 福島 直: 低電圧 ケーブルからの火災事例とその問題点. 安全工 学研究発表会講演予稿集, 147-150 (1999).

49）菊池光一，河村鴻允，能登文敏：地絡電流に よる $\mathrm{F}$ ケーブルの発火モードの検討。火災， 31(3), 34-42 (1981).

50）保坂光貞：絶縁電線に対する「ねずみ」の嗜 咬性とそれによる発火危険性. 日本火災学会大 会学術講演梗概集，97-98（1984）.

51）室田城治：電気設備の防鼠対策. 電設工業 (4) , 102-110 (1990).

52) 土方忠道 : 配線器具類加らの出火事例, 特徵 および問題点と対策。火災，46(2)，13-17 (1996).

53）東京消防庁調査課：火災発生事例一ダウンラ イトの火災一。炎災，40(4), 56-58（1990).

54）水本光浩, 井畑 康, 山口敏彦：白熱灯ダウ ンライトの過熱事故。火災，44(1), 35-39 (1994).

55）東京消防庁予防部調査課：広告用大型映写装 置加出火した火災。火災，49(2), 57-60 (1999).

56）松浦正博：直流低電圧によるフェノール樹脂 絶縁物の絶縁劣化とそれに伴う発火の現象. 火 災, 28(3), 17-23 (1978).

57）田村陽介，鈴木仁治：車両火災に打ける水消 火後のトラッキングによる発火. 日本火炎学会 研究発表会概要集, 280-281（1996）.

58）上山 勝：有機絶縁物の絶縁破壞（トラッキ ング）による炭化生成物の結晶性について。科 警研報告，28，102-105（1975）。 
59）舛井正義：火災によるビニルコードの溶融痕 への炭素の巻き込久の可能性. 電学論 $\mathrm{A}, 112$, 78-79 (1992).

60）諸田正規：ビニルコードの半断線箇所に生じ る溶融痕について。日本鑑識科学技術学会講演 要旨集, 123 (1997).

61）李 義平, 大谷英雄, 松原美之, 関 勉, 長谷川秀夫, 今田修二, 矢代 勲: 巻き込み炭 素残渣中の炭素結晶構造分析による 1 次 2 次 溶融痕の判別に関する研究. 日本火災学会論文 集, 50, 71-80 (2000).

62) Miyoshi, M: Internal Cavity analysis of Electrical Arc Beads. Proceed. the 4th Asia-Oceania Symposium on Fire Sci. and Tech., pp. 653-654, Asia-Oceania Association for Fire Sci. and Tech., Tokyo (2000).

63 ）李 義平, 大谷英雄, 関勉, 長谷川秀 夫, 今田修二, 矢代 勲: DAS による 1 次 $\cdot 2$ 次溶融痕の判別に関する研究. 日本火災学会論 文集，50，1-12 (2000).

64）木下勝博, 萩本安昭, 渡邊憲道: 有機絶縁材 料炭化物の電気的特性に及ぼす形成温度の検 討. 日本火災学会論文集，45，27-29（1996）。

65 ) 水島三知, 岡田 純: 炭素材料. pp. 7988, 共立出版, 東京 (1970).

66）木下勝博, 渡邊憲道 : 有機絶縁材料炭化物の 結晶の変化に及ぼす形成温度の検討. 日本火災 学会論文集, 46, 27-31（1997）.

67）木下勝博, 萩本安昭, 渡邊憲道, 岡本勝弘, 村口憲雄 : 有機絶縁材料の耐トラッキング性と 着火危険性との関係の検討. 日本鑑識科学技術 学会講演要旨集, 97 (1999).

68）木下勝博, 村口 憲雄 : 加熱劣化ポリスチレン の耐トラッキング性と着火危険性の関係. 日本 鑑識科学技術学会講演要旨集, 106 (2000).

69) Babrauskas, V.: How do Electrical Wiring Faults Lead to Structure Ignitions? Fire and Materials 2001, 7th International Conference, pp. 39-51, Inter Science Communications, London (2001).

70）萩原隆一, 萩本安昭 : $\mathrm{F}$ 形ビニルケーブルの
絶縁劣化による発火現象. 火災, 37(5), 46-50 (1987).

71）戸田芳徳：有機絶縁材料の劣化現象について 一PVCケーブルの熱劣化時における充填剤の 挙動. 火災, 24(3), 168-171 (1974).

72）三橋信雄, 桜井良秀, 長田正義, 井坂勝生 : 絶縁被覆電線の劣化履歴と火災危険について. 火災，31(1)，11-19（1981）。

73）長田正義 : 素線切れビニルコードの着火電流 と流入エネルギー。日本火災学会論文集， 33, 1-7 (1983).

74）長田正義，横井良秀：ビニルコードの高温劣 化と発火特性. 日本火災学会論文集，33，2529 (1983).

75）土方忠道, 小河原明人, 原實: 配線器具 にみられるトラッキング痕跡. 火災，41(6)， 34-37 (1991).

76）東京消防庁予防部調査課 : 差し込みプラグ両 刃間のトラッキング現象の研究. 火災，44(6), 32-37 (1994).

77）中野弘伸：電気配線からの発火原因に関する 考察，火災，46(2), 1-5 (1996).

78）芦澤清美, 小俣 桂: 差込プラグの熱劣化に よる発火メカニズムについて. 日本火災学会研 究発表会概要集, 386-389 (1997).

79）芦澤清美，土方忠道 : 差込プラグに加わる荷 重とコンセントの性能劣化について。日本鑑識 科学技術学会講演要旨集, 96 (1999).

80）芦澤清美: 差込プラグの熱劣化による発火機 構. 日本火災学会論文集，50，63-70（2000）。

81）岡本勝弘, 渡邊憲道, 萩本安昭, 木下勝博 : 電源接続箇所の接触抵抗の変化によるプラグ絶 縁材料の熱劣化. 日本火災学会研究発表会概要 集, 178-181 (1998).

82）岡本勝弘, 渡邊憲道, 萩本安昭, 木下勝博 : 電気絶縁材料の熱劣化による耐トラッキング性 の低下について. 日本火災学会研究発表会概要 集, 6-9 (1999).

83）岡本勝弘, 渡邊憲道, 萩本安昭, 木下勝博： プラグーコンセント接続部に抢けるプラグ絶縁 材料の熱劣化による火災危険性. 日本火災学会 
研究概要集, 248-251 (2000).

84）河村健太郎, 大谷英雄, 金城康人：PVC プ ラグの熱劣化に関する基礎的研究. 安全工学研 究発表会講演予稿集, 151-154 (1999).

85）小田英輔, 林 敏安：ケーブルの延燒性とそ の防止方法(4)難燃ケーブルについて．火災，29 (2) , 45-55 (1979).

86）青木健治：ケーブル火災と延焼防止方法. 火 災, 46(2), 23-27 (1996).

87）室田城治，矢島一男：ケーブルの延焼性とそ の防止方法(3)延焼防止対策とその効果. 火災， 29(1), 39-47 (1979).

88）室田城治：電線・ケーブルの防災対策. 電設 技術(5)，44-56 (2000).

89）河村鴻允：屋内配電線路におけるトラッキン グ事故の検知・防止装置の開発. 電学論 $\mathrm{A}$, 101, 559-566 (1981).

90）河村鴻允，能登文敏，坂本三郎：配電用ケ一 ブルのトラッキング劣化による電気着火現象々 電気火災防止装置の開発. 日本火災学会論文 集，31，23-30 (1981).

91）早川 進, 渡邊憲道 : 電気火災原因と保護ブ レーカの働き. 火災, 46(2), 18-22（1996）。

92) Gregory, G. D.: Using Arc-Fault Circuit Interrupters to Reduce Residential Fires. $E C \& M$,
Nov., 60-84 (1997).

93) Douglas, A. L., Andrew, M. T., William, H. K. Jr.: New Technology for Preventing Residential Electrical Fires: Arc-Fault Circuit Interrupters (AFCIs). Fire Technology, 36, 145-162 (2000).

94）溝口達夫, 山本忠之 : トラッキング火災防止 対策コンセントの開発. 日本火災学会研究発表 会概要集，406-409（1997）.

95）羽根良成, 松葉博則, 鈴木 洋, 深沢俊郎 : ケーブルの延焼性とその防止方法(2)リニア温度 センサーについて。炎災，28(6), 16-22 (1978).

96) http://www.jaish.gr.jp.

97） http://www.nrips.go.jp/section/second/fire/ jirei.html.

98) http://www.isad.or.jp/magzin/60_kyoto.htm.

99) http: // www.aist.go.jp / RIODB / cgi-pub019/ DB019_top_jpn.cgi.

100）竹内繁樹：火災の科学的原因調査の推進々安 全工学へのフィードバック。火災, 50 (5), 22 (2000).

101） 板生 清 : 21世紀のマイクロテクノロジー. 電学誌, 121, 56-60 (2001).

102) http://www.wearables.co.jp. 